\title{
DAMPAK LIBERALISASI PERDAGANGAN RI-CHINA TERHADAP PERUBAHAN PERDAGANGAN DAN KESEJAHTERAAN MASYARAKAT INDONESIA: SEBUAH PENDEKATAN EKUILIBRIUM PARSIAL (SMART MODEL) DAN PEMANFAATAN SISTEM NERACA SOSIAL EKONOMI 2008
}

\author{
Sulthon Sjahril Sabaruddin \\ Pusat Pengkajian dan Pengembangan Kebijakan Kawasan Amerika dan Eropa \\ Kementerian Luar Negeri Republik Indonesia \\ sulthon.sjahril@kemlu.go.id,ssabaruddin@yahoo.com
}

\begin{abstract}
This paper attempts to evaluate the impact of Indonesia-China trade liberalisation in changing Indonesian trade and Indonesian society welfare. To evaluate such impact, the study uses the Software for Market Analysis and Restrictions on Trade (SMART Model) and Social Accounting Matrix 2008 (SAM 2008). Based on the result of the Indonesia-China trade liberalizationscenario analysis, it is found that the net income received by the households due to the foreign trade with China is negative, which means the amount of the household expenditure due to the huge amount of Chinese commodities entering Indonesia is still higher compared to the amount of the household income received as a result of the Indonesian export of its commodities to China. The increased net income is enjoyed by all types of households.
\end{abstract}

Keywords: free trade, trade liberalisation, partial equilibrium analysis, software for market analysis and restrictions on trade (SMART) model

JEL classification numbers: F14, F15, F17

\section{PENDAHULUAN}

Hubungan perdagangan bilateral RI-China telah berkembang dengan pesat khususnya sejak penandatanganan Kemitraan Strategis RI-China pada tahun 2005 serta berlakunya Early Harvest Program pada tanggal 1 Januari 2004 (0 persen pada tahun 2006). Lebih lanjut, hubungan perdagangan bilateral RI-China terus menunjukkan peningkatan yang pesat khususnya beberapa tahun belakangan ini, namun puncaknya terjadi setahun setelah berlakunya ASEAN China Free Trade Aggrement(ACFTA) per Januari 2010 lalu (penerapan fase kedua ACFTA). Perdagangan RI-China meningkat secara signifikan dari US\$36,11 Milyar (2010) menjadi US\$49,15 Milyar (2011).Jika ditelusuri sejak memasuki abad milenium ini, terlihat bahwa hubungan perdagangan bilateral Indonesia-China meningkat pesat dari 
hanya US\$4,8 Milyar (2000) dan mencapai puncaknya sebesar US\$49 Milyar (2011).Angka nilai perdagangan tersebut merupakan yang tertinggi sepanjang sejarah hubungan perdagangan bilateral RI-China. Selain itu, nilai perdagangan tersebut melampaui target volume perdagangan sebesar US\$30 Milyar dan dengan sangat optimis nilai US\$50 Milyarpun yang dicanangkan pada tahun 2010 (Periode 2010-2015) oleh Presiden Susilo Bambang Yudhoyono akan dapat dicapai lebih cepat.

Pesatnya peningkatan hubungan perdagangan RI-China setidaknya tidak terlepas dari dua faktor pendorong utama yakni: proses liberalisasi ekonomi Indonesia akibat krisis ekonomi dan keuangan 1997-1998 lalu dan political will kedua negara dalam menjalin kerja sama ekonomi baik dalam konteks bilateral melalui kesepakatan kemitraan strategis pada tahun 2005 maupun regional dalam bentuk kesepakatan ACFTA yang pada Januari 2010 lalu telah efektif berjalan secara penuh (full implementation). Selain alasan diatas, tentu terdapat faktor lainnya seperti terapresiasinya Rupiah terhadap Dolar AS yang turut berkontribusi terhadap meningkatnya impor dengan pesat (Chandra dan Lontoh 2011). Namun demikian dibalik kesuksesan dalam meningkatkan hubungan perdagangan RI-China tersebut, sekarang yang menjadi pertanyaan strategis dan tentu sangat penting adalah, bagaimana dampaknya peningkatan drastis hubungan perdagangan RI-China ini terhadap tingkat kesejahteraan masyarakat dan daya saing ekspor Indonesia.

Pesatnya hubungan perdagangan kedua negara tentu jika dilihat dari sisi kerja sama hubungan diplomatik kedua negara, maka meningkatnya hubungan perdagangan bilateral tentu merupakan indikator positif dalam mempererat hubungan kerja sama ekonomi kedua negara. Namun demikian pesatnya peningkatan perdagangan kedua negara perlu dicermati lebih mendalam mengingat terdapat berbagai kemungkinan potensi implikasi terhadap perekonomian Indonesia. Banyak studi telah dilakukan terkait dampak perdagangan bebas RI-China terhadap perekonomian Indonesia seperti perubahan jumlah lapangan kerja, perubahan upah, perubahan perdagangan, serta pertumbuhan ekonomi.

Namun dalam studi ini, penelitian akan fokus pada implikasi liberalisasi perdagangan RI-China terhadap perubahan ekspor dan impor serta kesejahteraan masyarakat Indonesia.Tak dapat dipungkiri bahwa kerja sama perdagangan akan meningkatkan kompetisi antar anggota. Namun, apabila hal tersebut disikapi dengan bijak maka manfaat yang dapat dipetik antara lain adalah peningkatan spesialisasi dan peningkatan perdagangan itu sendiri. Dengan keunggulan komparatif dari masing-masing negara, setiap negara dapat berfokus pada produksi barang yang mempunyai keunggulan komparatif sehingga akan terjadi realokasi faktor produksi. Pada akhirnya akan tercipta keseimbangan harga yang lebih murah dan output yang lebih banyak sehingga memberikan kesejahteraan lebih besar terhadap negara-negara yang terlibat. 


\section{LANDASAN TEORI}

\section{Hambatan Perdagangan Tarif dan Non-Tarif dan Kesejahteraan,Tinjauan Teori Hambatan Perdagangan Internasional: Dampak Tarif terhadap Perdagangan Internasional}

Dalam prakteknya, perdagangan internasional dilakukan atas dasar kesepakatan bersama antar negara yang terlibat. Oleh karena itu, sering kali perdagangan tersebut dibatasi oleh berbagai hambatan berupa pajak (tarif) dan berbagai biaya lain terkait regulasi terhadap barang ekspor maupun impor. Hambatan perdagangan yang dilakukan oleh suatu negara pada dasarnya dilakukan antara lain untuk: melindungi produk lokal dari persaingan terhadap produk luar negeri, memperbaiki daya saing produk dalam negeri, mengurangi pengangguran dan memperbaiki posisi neraca pembayaran. Hambatan perdagangan yang sering digunakan adalah tarif yang merupakan pajak bagi barang impor yang masuk ke suatu negara. Di samping itu, masih ada hambatan perdagangan lain yang berbentuk non-tarif, antara lain berupa: kuota, larangan impor, subsidi dan dumping.

Tarif merupakan kebijakan perdagangan yang paling umum, adalah sejenis pajak yang dikenakan atas barang-barang yang diimpor. Tarif spesifik (specific tariffs) dikenakan sebagai beban tetap unit barang yang diimpor (misalnya, US $\$ 3$ untuk setiap barel minyak). Sedangkan tarif ad valorem (ad valorem tariffs) adalah pajak yang dikenakan berdasarkan presentase tertentu dari nilai barang-barang yang diimpor (misalnya, suatu negara memungut tarif 25 persen atas setiap unit mobil yang diimpor). Dalam kedua kasus ini, tarif menimbulkan dampak berupa kenaikan harga atau biaya pengiriman barang (produk impor) ke suatu negara. Untuk menganalisa dampak tarif terhadap perdagangan internasional dan kesejahteraan, dapat dilihat dari dua pendekatan: 1) pendekatan kesejahteraan dan 2) pendekatan offer curves.

a. Dampak tarif terhadap kesejahteraan: analisa biaya dan manfaat.

Secara ekonomi, adanya hambatan perdagangan (berupa tarif terhadap barang impor) sesungguhnya mengurangi keuntungan yang akan didapat oleh konsumen (consumer surplus) dan memberi tambahan keuntungan bagi produsen (producer surplus) dan serta menambah pendapatan (revenue) bagi pemerintah. Ilustrasi keadaan ini diperlihatkan dalam Gambar 1. Dalam keseimbangan autarky (Gambar 1a), keseimbangan perekonomian berada di titik I, dimana keuntungan konsumen adalah seluas areal AIJ, sementara produsen akan mendapatkan keuntungan seluas areal CIJ. Dengan adanya perdagangan (bebas) internasional, titik keseimbangan telah bergeser ke titik B pada level harga sebesar $\mathrm{P}^{*}$, dengan keuntungan konsumen sebesar $\mathrm{ABC}$ dan keuntungan produsen sebesar CDE. Dalam kondisi demikian, perdagangan (bebas) internasional telah memberikan tambahan keuntungan bagi konsumen dan mengurangi keuntungan produsen. Konsumen mendapatkan keuntungan lebih dengan harga barang (impor) yang lebih rendah, sebaliknya 
produsen terkurangi pendapatannya karena konsumen memilih barang (impor) dengan harga yang lebih rendah.

Pemerintah kemudian menetapkan tarif sebesar $t$ terhadap barang (impor) yang masuk (Gambar 1b) demi melindungi produk lokal terhadap persaingan dengan produk impor. Penetapan tarif impor ini telah mengakibatkan harga naik menjadi sebesar $\mathrm{P}^{*}+$ t. Dengan meningkatnya harga pada level ini, pemerintah telah mendapatkan tambahan pendapatan sebesar GHKL dan produsen mendapatkan kembali keuntungannya hingga menjadi sebesar EFG. Sementara itu, konsumen hanya dapat mengambil keuntungan sebesar AFH. Dengan adanya tarif sebenarnya masih ada bagian keuntungan yang seharusnya bisa diambil akan tetapi tidak bisa diperoleh; dengan kata lain penetapan tarif oleh pemerintah secara teori memiliki potensi kerugian (deadweight loss) seluas area DGL ditambah HBK.

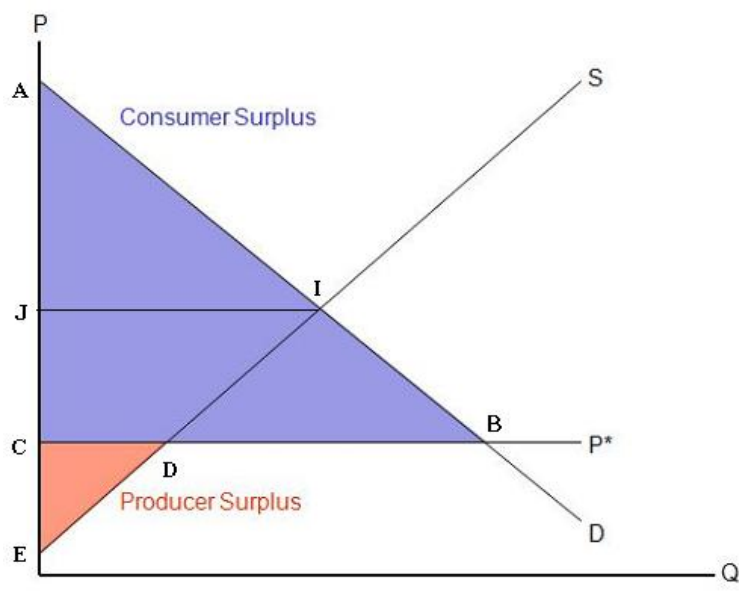

a)Tanpa tarif

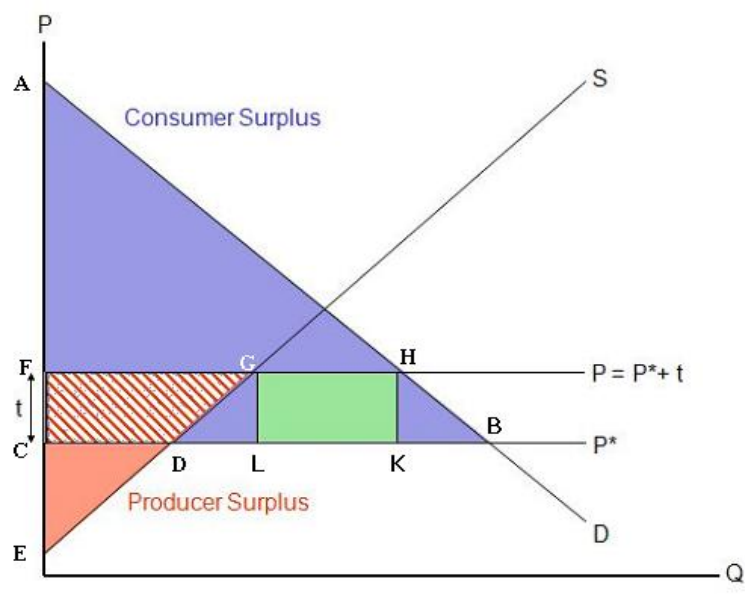

b) Dengan tarif

Sumber: Krugman (2005).

\section{Gambar 1}

Dampak Pemberlakuan Tarif Terhadap Suatu Perekonomian

b. Dampak tarif dengan pendekatan offer curves: penurunan tarif secara bilateral.

Cara lain untuk mengevaluasi dampak liberalisasi perdagangan terhadap kesejahteraan suatu negara, menurut Krugman (2005) dapat dianalisis melalui pendekatan offer curve (kurva tawar menawar). Offer curve pada suatu negara menggambarkan berapa banyak suatu negara berkeinginan untuk melakukan ekspor dan impor pada beberapa harga relatif komoditi (rasio harga perdagangan internasional).Kurva ini dapat dikatakan juga sebagai interaksi antara kurva penawaran ekspor dan kurva penawaran impor suatu negara dan merupakan fungsi dari rasio harga perdagangan. Offer curve diturunkan dari nation's production frontier, indifference map dan beberapa relative commodity prices dimana perdagangan terjadi. Dalam menjelaskan dampak penurunan tarif secara bilateral dengan memanfaatkan offer curve, secara garis besar penulis akan merangkum dan 
mengikuti literatur yang disampaikan oleh Widjaja (2000). Dalam Gambar 2, sebuah offer curve dari negara $\mathrm{H}$, dimana barang $\mathrm{E}$ dan I adalah barang ekspor dan impor dari negara yang bersangkutan, untuk setiap rasio harga perdagangan tertentu, maka negara $\mathrm{H}$ menghasilkan suatu kuantitas ekspor tertentu, yang sedia ditukarkan dengan kuantitas impor tertentu.

Perjanjian pengurangan tarif secara bilateral dapat terbentuk: (a) kedua negara menghilangkan tarif, atau (b) kedua negara hanya sepakat mengurangi tarif. Untuk melihat dampaknya terhadap negara Indonesia dapat dilihat Gambar 2 Offer curve $\mathrm{OH}$ (Indonesia) dan $\mathrm{OF}$ (negara lainnya) berpotongan pada titik $\mathrm{T}$ dan kurva indiferen negara $\mathrm{H}$ adalah $\mathrm{h}_{1}$. Jika kedua negara mengenakan tarif, titik potong keseimbangan perdagangan berada di dalam offer curve $\mathrm{OH}$ dan $\mathrm{OF}$ seperti misalnya pada titik S dengan offer curve masing-masing pada $\mathrm{OH}^{\prime}$ dan OF'. Pembebasan tarif bilateral akan menggeser titik keseimbangan menuju titik $\mathrm{T}$ dan akan meningkatkan kesejahteraan kedua negara. Kesejahteraan negara Indonesia akan meningkat dari $\mathrm{h}_{2}$ $\mathrm{ke} \mathrm{h}_{1}$. Bila titik keseimbangan awal dengan adanya tarif ada pada daerah $\mathrm{M}$, maka pembebasan tarif bilateral justru akan merugikan Indonesia karena kesejahteraan menurun yang ditunjukkan dengan makin rendahnya kurva indiferen yang dicapai, sehingga bagi Indonesia adanya liberalisasi perdagangan justru merugikan. Sebaliknya apabila titik keseimbangan perdagangan awal dengan adanya tarif berada dalam $\mathrm{OH}$ dan $\mathrm{OF}$ tetapi diluar daerah $\mathrm{M}$, maka pembebasan tarif akan menguntungkan Indonesia.

Dari gambaran tersebut tampak bahwa dampak liberalisasi perdagangan tidak selalu menguntungkan suatu negara. Bagaimana dampaknya apabila yang terjadi adalah pengurangan tarif saja. Pengurangan tarif akan menguntungkan kedua negara bila menuju daerah $\mathrm{V}$ (daerah yang diberi arsir) dan pengurangan tarif selanjutnya dalam rangka pembebasan tarif masih tetap menguntungkan kedua belah pihak. Dengan demikian daerah yang diarsir merupakan daerah yang menguntungkan kedua belah pihak untuk mengadakan perjanjian pengurangan tarif menuju perdagangan bebas (titik $\mathrm{T}$ ). Bila pengurangan tarif menuju daerah $\mathrm{M}$ atau $\mathrm{N}$, nantinya ketika terjadi pembebasan tarif hanya menguntungkan salah satu negara saja (daerah $\mathrm{M}$ merugikan negara $\mathrm{H}$, daerah $\mathrm{N}$ merugikan negara $\mathrm{F}$ ). 


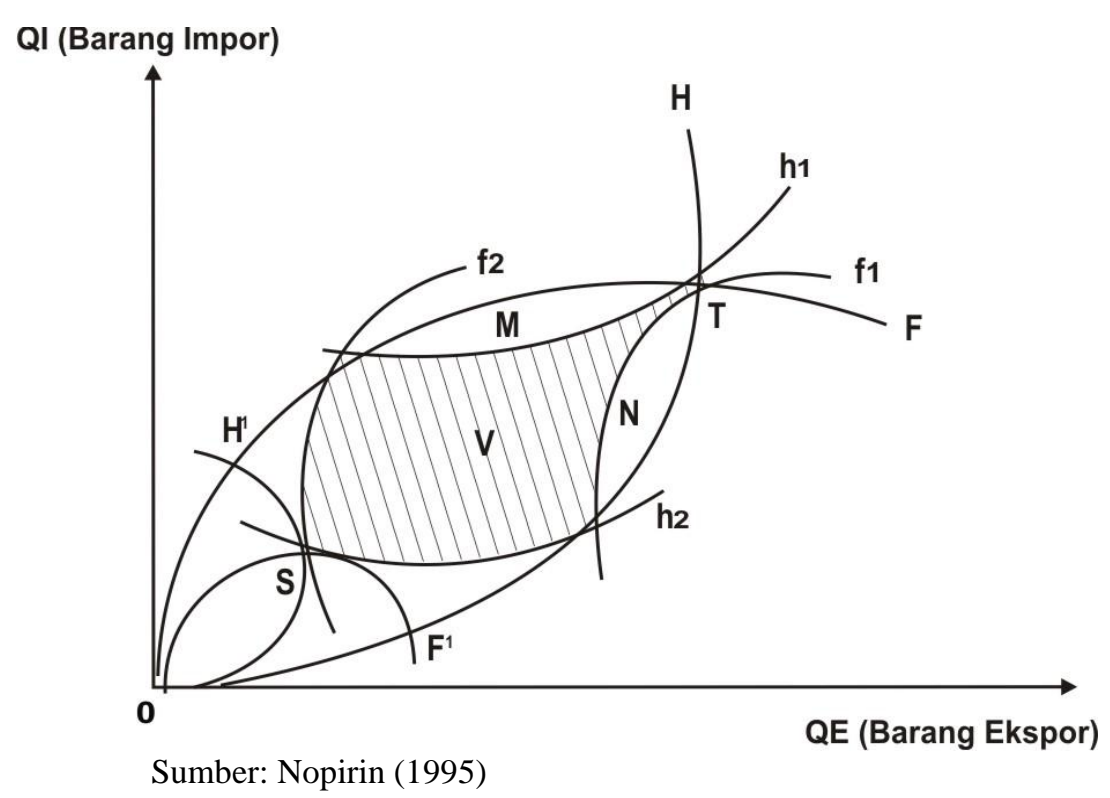

Gambar 2

Liberalisasi Perdagangan Bilateral

\section{METODA PENELITIAN}

Pada studi ini, sejumlah perangkat akan dimanfaatkan dalam mengevaluasi dampak liberalisasi perdagangan RI-China terhadap perubahan ekspor dan impor serta kesejahteraan di Indonesia. Perangkat yang akan digunakan dalam kajian ini adalah Software for Market Analysis and Restrictions on Trade (SMART Model) dan Sistem Neraca Sosial Ekonomi 2008 untuk melihat secara umum dampak liberalisasi perdagangan luar negeri yang dilakukan Indonesia. Pemanfaatan SMART Model adalah untuk mengevaluasi simulasi penerapan kebijakan nol tarif (full tariff dismantlement) terhadap perubahan ekspor dan impor. SMART Model merupakan model simulasi perdagangan ekuilibrium parsial, yang digunakan untuk menilai dampak liberalisasi perdagangan atau perdagangan bebas terhadap perdagangan (trade), pendapatan tarif (tariff revenue) dan kesejahteraan (welfare effects). Namun dalam kajian ini, dampak yang akan dianalisa hanya terhadap perdagangan saja.

Hasil simulasi menggunakan SMART Model lebih lanjut dimanfaatkan sebagai trade shock terhadap sektor-sektor di dalam SNSE 2008, yakni melalui perubahan ekspor dan impor di Indonesia, untuk melihat dampak secara khusus liberalisasi perdagangan RI-China terhadap kesejahteraan masyarakat yang dilihat dari sisi pendapatan rumah tangga. Sistem Neraca Sosial Ekonomi (SNSE) merupakan suatu sistem kerangka data yang disajikan dalam bentuk matriks, yang memberikan gambaran mengenai kondisi ekonomi dan sosial masyarakat dan keterkaitan antara keduanya secara komprehensif, konsisten dan terintegrasi (BPS 2010). Sebagai suatu sistem kerangka data yang komprehensif dan terintegrasi, SNSE mencakup berbagai data ekonomi dan sosial secara konsisten karena 
menjamin keseimbangan transaksi dalam setiap neraca yang terdapat di dalamnya. SNSE juga bersifat modular karena dapat menghubungkan berbagai variabel ekonomi dan sosial di dalamnya, sehingga keterkaitan antar variabel-variabel tersebut dapat diperlihatkan dan dijelaskan (Badan Pusat Statistik 2010).

Matriks SNSE yang dianalisis dalam subbab ini 105x105 yang terdiri dari 105 akun dan mengelompokkan sistem perekonomian Indonesia ke dalam empat neraca, yaitu: neraca faktor produksi yang terdiri dari 17 klasifikasi (tenaga kerja, 16 klasifikasi dan bukan tenaga kerja); neraca institusi yang terdiri dari 10 klasifikasi (rumah tangga, 8 klasifikasi;perusahaan dan pemerintah); neraca produksi (activities) yang terdiri dari 74 klasifikasi (sektor produksi, komoditi domestik dan komoditi impor yang masing-masing terdiri dari 24 klasifikasi; serta margin perdagangan dan pengangkutan); serta neraca eksogen yang terdiri dari empat klasifikasi (Neraca Kapital, Pajak Tidak Langsung, Subsidi dan Neraca Luar Negeri).

Sebagaimana disampaikan diatas berdasarkan hasil olahan SMART diatas, maka kini penelitian ini memanfaatkan variabel perubahan impor dan ekspor untuk dimasukkan ke dalam model SNSE 2008, guna pada akhirnya melihat dampak trade shock terhadap perubahan pendapatan rumah tangga dari masing-masing sektor. Sebelum melakukan trade shock terhadap SNSE 2008, penelitian ini melakukan proses konversi terlebih dahulu guna menyesuaikan output dari SMART Model maupun data ekspor-impor yang memiliki kode komoditi berupa Harmonized System (HS Code) dengan kode komoditi yang ada dalam SNSE 2008. Proses konversi dan pengolahan data secara agregat ke dalam kode komoditi SNSE 2008 dilakukan dengan menggunakan formula yang tersedia dalam MS Excel. Untuk setiap komoditi, proses konversi dilakukan dengan tahapan sebagai berikut.

1. Proses konversi dari kode HS 2007 ke kode HS 2004. Kode konversi diperoleh dari Direktorat Bea dan Cukai, Kementerian Keuangan Republik Indonesia.

2. Proses konversi dari kode HS 2004 yang didapat pada tahap 1 ke kode Klasifikasi Baku Lapangan Usaha Indonesia (KBLI) 2005. Kode konversi diperoleh dari Direktorat Pengembangan Metodologi Survei dan Sensus, Badan Pusat Statistik.

3. Proses konversi dari kode KBLI 2005 yang didapat pada tahap 2 ke kode komoditi SNSE 2008. Kode konversi ini diperoleh dari Direktorat Neraca Pengeluaran, Badan Pusat Statistik. 
Tabel 1

Kodifikasi Sektor Produksi/Komoditi di dalam SNSE 2008

\begin{tabular}{|c|c|c|c|c|}
\hline \multicolumn{3}{|c|}{ Kode di dalam SNSE 2008} & \multirow[b]{2}{*}{ Keterangan Kode (24 Subsektor) } & \multirow{2}{*}{$\begin{array}{l}\text { Keterangan Kode } \\
\quad(9 \text { Sektor })\end{array}$} \\
\hline $\begin{array}{c}\text { Sektor } \\
\text { Produksi }\end{array}$ & $\begin{array}{l}\text { Komoditi } \\
\text { Domestik } \\
\end{array}$ & $\begin{array}{l}\text { Komoditi } \\
\text { Impor }\end{array}$ & & \\
\hline 28 & 54 & 78 & 1. Pertanian Tanaman Pangan & \multirow{5}{*}{ 1. Pertanian } \\
\hline 29 & 55 & 79 & 2. Pertanian Tanaman Lainnya & \\
\hline 30 & 56 & 80 & 3. Peternakan dan Hasil-hasilnya & \\
\hline 31 & 57 & 81 & 4. Kehutanan dan Perburuan & \\
\hline 32 & 58 & 82 & 5. Perikanan & \\
\hline 33 & 59 & 83 & $\begin{array}{l}\text { 6. Pertambangan Batubara, Biji } \\
\text { Logam dan Minyak Bumi }\end{array}$ & \multirow{2}{*}{$\begin{array}{l}\text { 2. Pertambangan } \\
\text { \& Penggalian }\end{array}$} \\
\hline 34 & 60 & 84 & $\begin{array}{l}\text { 7. Pertambangan dan Penggalian } \\
\text { Lainnya }\end{array}$ & \\
\hline 35 & 61 & 85 & $\begin{array}{l}\text { 8. Industri Makanan, Minuman dan } \\
\text { Tembakau }\end{array}$ & \multirow{5}{*}{ 3. Industri } \\
\hline 36 & 62 & 86 & $\begin{array}{l}\text { 9. Industri Pemintalan, Tekstil, } \\
\text { Pakaian dan Kulit }\end{array}$ & \\
\hline 37 & 63 & 87 & $\begin{array}{l}\text { 10. Industri Kayu \& Barang dari } \\
\text { Kayu }\end{array}$ & \\
\hline 38 & 64 & 88 & $\begin{array}{l}\text { 11. Industri Kertas, Percetakan, Alat } \\
\text { Angkutan dan Barang Dari } \\
\text { Logam dan Industri Lainnya }\end{array}$ & \\
\hline 39 & 65 & 89 & $\begin{array}{l}\text { 12. Industri Kimia, Pupuk, Hasil } \\
\text { Dari Tanah Liat, Semen }\end{array}$ & \\
\hline 40 & 66 & 90 & 13. Listrik, Gas dan Air Bersih & \multirow{2}{*}{$\begin{array}{l}\text { 4. Listrik, Gas \& } \\
\text { Air Bersih } \\
\text { 5. Konstruksi }\end{array}$} \\
\hline 41 & 67 & 91 & 14. Konstruksi & \\
\hline 42 & 68 & 92 & 15. Perdagangan & \multirow{4}{*}{$\begin{array}{l}\text { 6. Perdagangan, } \\
\text { Restoran \& } \\
\text { Hotel }\end{array}$} \\
\hline 43 & 69 & 93 & 16. Restoran & \\
\hline 44 & 70 & 94 & 17. Perhotelan & \\
\hline 45 & 71 & 95 & 18. Angkutan Darat & \\
\hline 46 & 72 & 96 & $\begin{array}{l}\text { 19. Angkutan Udara, Air dan } \\
\text { Komunikasi }\end{array}$ & \multirow{2}{*}{$\begin{array}{l}\text { 7. Angkutan \& } \\
\text { Komunikasi }\end{array}$} \\
\hline 47 & 73 & 97 & $\begin{array}{l}\text { 20. Jasa Penunjang Angkutan dan } \\
\text { Pergudangan }\end{array}$ & \\
\hline 48 & 74 & 98 & 21. Bank dan Asuransi & \multirow{2}{*}{$\begin{array}{l}\text { 8. Keuangan \& } \\
\text { Jasa } \\
\text { Perusahaan }\end{array}$} \\
\hline 49 & 75 & 99 & 22. Real Estate dan Jasa Perusahaan & \\
\hline 50 & 76 & 100 & $\begin{array}{l}\text { 23. Pemerintahan dan Pertahanan, } \\
\text { Pendidikan, Kesehatan, Film dan } \\
\text { Jasa Sosial Lainnya }\end{array}$ & \multirow[t]{2}{*}{ 9. Jasa-jasa } \\
\hline 51 & 77 & 101 & $\begin{array}{l}\text { 24. Jasa Perseorangan, Rumah } \\
\text { tangga dan Jasa Lainnya }\end{array}$ & \\
\hline
\end{tabular}




\section{Dampak Liberalisasi Perdagangan RI-China terhadap Perubahan Nilai Perdagangan RI-China dan Kesejahteraan Masyarakat}

Pada subbab ini, hasil dengan memanfaatkan perangkat WITS/SMARTpartial equilibrium model menggambarkan dampak dari liberalisasi perdagangan RI-China pada tahun 2009 dengan skenario liberalisasi penuh atau complete tariff dismantlement (tarif nol) terhadap perekonomian Indonesia. Dalam studi ini, penelitian inihanya akan mengevaluasi dampak terhadap perubahan ekspor dan impor saja, sedangkan dampak terhadap perekonomian seperti kesejahteraan dan pendapatan tarif tidak dibahas dalam makalah ini. Dalam analisis penulis menggunakan tiga Digit SITC Revisi dua.

\section{Dampak terhadap Perubahan Impor dan Ekspor: Sebuah Pendekatan SMART Model}

a. Dampak terhadap Perubahan Impor Indonesia

Dampak liberalisasi perdagangan RI-China tentu akan meningkatkan impor Indonesia dari China akibat penurunan harga produk impor dari China. Perubahan impor merupakan trade creation effect, maka tingginya perubahan impor (dalam hal ini adanya peningkatan impor) menggambarkan besarnya trade creation effect atau dampak penciptaan perdagangan. Total perubahan impor akibat liberalisasi perdagangan RI-China tahun 2009 (nol tarif) adalah diprediksi meningkat sebesar US\$1,24 Milyar, sedangkan pada tahun 2010 meningkat sebesar US\$458,683 Milyar.

Pada tahun 2009, peningkatan impor terbesar (perubahan impor) dari China setelah diberlakukannya liberalisasi perdagangan RI-China secara penuh adalah SITC 785 (Motorcycles, Motor Scooters and Other Cycles, Motorized and NonMotorized; Invalid Carriages) sebesar US\$305,2 Juta diikuti SITC 843 (Outer Garments, Women's, Girls and Infants, of Textile Fabrics; other than knitted or crocheted goods) sebesar US\$122,4 Juta. Kedua produk tersebut mewakili 34,4 persen dari total perubahan impor Indonesia. Sedangkan pada tahun 2010, peningkatan impor terbesar (perubahan impor) dari China setelah diberlakukannya liberalisasi perdagangan RI-China secara penuh adalah SITC 785 (Motorcycles, Motor Scooters and Other Cycles, Motorized and Non-Motorized; Invalid Carriages) sebesar US\$162 Juta diikuti SITC 843 (Outer Garments, Women's, Girls and Infants, of Textile Fabrics; other than knitted or crocheted goods) sebesar US\$70,191 Juta dan SITC 661 (Lime, Cement, and Fabricated Constuction Materials Except Glass and Clay Materials) sebesar US\$34,368 Juta. Berikut adalah Tabel 5 produk impor dengan peningkatan impor terbesar (perubahan impor terbesar) pada tahun 2009 dan 2010 setelah diberlakukannya liberalisasi perdagangan RIChina: 
Tabel 2

Top 5 Produk dengan Peningkatan Impor Terbesar

Setelah Diberlakukannya Liberalisasi Perdagangan RI-China 2009

\begin{tabular}{clcc}
\hline ProductCode & \multicolumn{1}{c}{ ProductName } & $\begin{array}{c}\text { ImportBefore } \\
\text { (Million USD) }\end{array}$ & $\begin{array}{c}\text { ImportChange } \\
\text { (Million USD) }\end{array}$ \\
\hline 785 & $\begin{array}{l}\text { Motorcycles, Motor Scooters and Other Cycles, } \\
\text { Motorized and Non-Motorized; Invalid Carriages }\end{array}$ & 975,36 & 305,18 \\
843 & $\begin{array}{l}\text { Outer Garments, Women's, Girls and Infants, of } \\
\text { Textile Fabrics; other than knitted or crocheted } \\
\text { goods }\end{array}$ & 87,99 & 122,44 \\
645 & $\begin{array}{l}\text { Outer Garments and Other Articles, Knitted or } \\
\text { Crocheted, not Elastic nor Rubberized }\end{array}$ & 301,77 & 97,85 \\
716 & $\begin{array}{l}\text { Fabrics, Woven, of Man-Made Fibres (not } \\
\text { including Narrow or Special Fabrics) }\end{array}$ & 532,64 & 55,72 \\
Rotating Electric Plant and Parts thereof, n.e.s. & 964,24 & 46,19 \\
\hline
\end{tabular}

Sumber: WITS 2012

Tabel 3

Top 5 Produk dengan Peningkatan Impor Terbesar

Setelah Diberlakukannya Liberalisasi Perdagangan RI-China 2010

\begin{tabular}{|c|c|c|c|}
\hline $\begin{array}{l}\text { ProductC } \\
\text { ode }\end{array}$ & ProductName & $\begin{array}{c}\text { Import } \\
\text { Before } \\
\text { (Million } \\
\text { USD) }\end{array}$ & $\begin{array}{c}\text { ImportChan } \\
\text { ge } \\
\text { (Villion } \\
\text { USD) }\end{array}$ \\
\hline 785 & $\begin{array}{l}\text { Motorcycles, Motor Scooters and Other Cycles, } \\
\text { Motorized and Non-Motorized; Invalid Carriages }\end{array}$ & 737,39 & 162,01 \\
\hline 843 & $\begin{array}{l}\text { Outer Garments, Women's, Girls and Infants, of Textile } \\
\text { Fabrics; other than knitted or crocheted goods }\end{array}$ & 58,59 & 70,19 \\
\hline 661 & Lime, Cement, and Fabricated Construction Materials & 161,71 & 34,37 \\
\hline 662 & $\begin{array}{l}\text { Clay Construction Materials and Refractory } \\
\text { Construction Materials }\end{array}$ & 120,31 & 21,30 \\
\hline 893 & $\begin{array}{l}\text { Articles, n.e.s, of materials of the kinds described in } \\
\text { division } 58-\text { Plastics }\end{array}$ & 639,58 & 18,69 \\
\hline
\end{tabular}

Sumber: WITS 2012

b. Dampak terhadap Perubahan Ekspor Indonesia

Dengan memberikan bebas bea cukai (nol tarif) kepada Indonesia untuk masuk ke pasar China dimana merupakan pasar terbesar di dunia dengan total penduduk mencapai 1,34 Milyar dan sebagai negara dengan perekonomian kedua terbesar di dunia, maka liberalisasi perdagangan RI-China akan secara signifikan mendorong peningkatan ekspor Indonesia ke China. Dengan pemberlakuan liberalisasi perdagangan RI-China tahun 2009 dan 2010, maka diprediksi terjadi peningkatan ekspor Indonesia ke China sebesar US\$346,7 Juta (2009) dan US\$579,695 Juta (2010). 
Pada tahun 2009, dua produk ekspor dengan peningkatan ekspor Indonesia terbesar (perubahan ekspor) ke China adalah: produk SITC 334 (Petroleum Products, Refined) sebesar US\$159 Juta, diikuti SITC 424 (Other Fixed Vegetable Oils, Fluid or Solid, Crude, Refined or Purified) sebesar US\$108,81 Juta. Kedua produk tersebut mendominasi sebesar 77,23 persen dari total perubahan ekspor Indonesia ke China. Adapun produk ekspor lainnya yang mengalami peningkatan besar adalah SITC 641 (Paper and Paperboard) sebesar US\$9,17 Juta, SITC 512 (Alcohols, Phenols, Phenol-Alcohols and their Halogenated, Sulphonated, Nitrated or Nitrosated Derivatives) sebesar US\$7,97 Juta dan SITC 583 (Polymerization and Copolymerization Products) sebesar US\$7,41 Juta.

Sedangkan pada tahun 2010, lima produk ekspor dengan peningkatan ekspor Indonesia terbesar (perubahan ekspor) ke China adalah produk SITC 785 (Motorcycles, Motor Scooters and Other Cycles, Motorized and Non-Motorized; Invalid Carriages) sebesar US\$176,549 Juta, diikuti SITC 843 (Outer Garments, Women's, Girls and Infants, of Textile Fabrics; other than knitted or crocheted goods) sebesar US\$70,95 Juta; SITC 661 (Lime, Cement, and Fabricated Constuction Materials Except Glass and Clay Materials) sebesar US\$34,927 Juta; SITC 893 (Articles, n.e.s, of materials of the kinds described in division 58-Plastics) sebesar US\$30,723 Juta dan SITC 674 (Universals, Plates and Sheets, of Iron or Steel) sebesar US\$30,629 Juta. Kelima produk tersebut mewakili 59,3 persen dari total peningkatan ekspor Indonesia akibat diberlakukannya nol tarif produk ekspor Indonesia ke China. Berikut adalah Tabel 5 produk ekspor dengan peningkatan terbesar akibat diberlakukannya liberalisasi perdagangan RI-China:

Tabel 4

Top 5 Produk dengan Peningkatan Ekspor Terbesar Setelah Diberlakukannya Liberalisasi Perdagangan RI-China Tahun 2009

\begin{tabular}{|c|c|c|}
\hline $\begin{array}{l}\text { Product } \\
\text { Code }\end{array}$ & Product Name & $\begin{array}{c}\text { Export Change In } \\
\text { Revenue in million USD }\end{array}$ \\
\hline 334 & Petroleum Products, Refined & 159,01 \\
\hline 424 & $\begin{array}{l}\text { Other Fixed Vegetable Oils, Fluid or Solid, Crude, Refined } \\
\text { or Purified }\end{array}$ & 108,81 \\
\hline 641 & Paper and Paperboard & 9,17 \\
\hline 512 & $\begin{array}{l}\text { Alcohols, Phenols, Phenol-Alcohols, and their Halogenated, } \\
\text { Sulphonated, Nitrated or Nitrosated Derivatives }\end{array}$ & 7,97 \\
\hline 583 & Polymerization and Copolymerization Products & 7,41 \\
\hline
\end{tabular}


Tabel 5

Top 5 Produk dengan Peningkatan Ekspor Terbesar setelah Diberlakukannya Liberalisasi Perdagangan RI-China Tahun 2010

\begin{tabular}{clc}
\hline $\begin{array}{c}\text { Product } \\
\text { Code }\end{array}$ & \multicolumn{1}{c}{ Product Name } & $\begin{array}{c}\text { Export Change In } \\
\text { Revenue in million USD }\end{array}$ \\
\hline 785 & $\begin{array}{l}\text { Motorcycles, Motor Scooters and Other Cycles, Motorized } \\
\text { and Non-Motorized; Invalid Carriages }\end{array}$ & 176,55 \\
843 & $\begin{array}{l}\text { Outer Garments, Women's, Girls and Infants, of Textile } \\
\text { Fabrics; other than knitted or crocheted goods }\end{array}$ & 70,95 \\
661 & $\begin{array}{l}\text { Lime, Cement, and Fabricated Constuction Materials Except } \\
\text { Glass and Clay Materials }\end{array}$ & 34,93 \\
893 & $\begin{array}{l}\text { Articles, n.e.s, of materials of the kinds described in division } \\
68-\text { Plastics }\end{array}$ & 30,72 \\
\hline Universal, Plates and Sheets, of Iron or Steel & 30,63 \\
\hline
\end{tabular}

Sumber: World Integrated Trade Solutions (WITS) 2012

\section{Dampak Liberalisasi Perdagangan RI-China terhadap Perubahan Impor dan Ekspor (Periode 2009 dan 2010)}

Pada sub bab ini, penelitian ini mengevaluasi dan melakukan analisa komparatif liberalisasi perdagangan RI-China dengan nol tarif pada tahun 2009 dan 2010 terhadap perubahan impor dan ekspor dengan memanfaatkan hasil olahan dari perangkat SMART Model. Dalam mengevaluasi dampak liberalisasi perdagangan RIChina, penelitian menggunakan data SITC satu Digit Revisi dua. Adapun tujuan pengunaan SITC satu Digit ini adalah untuk melihat gambaran perubahan impor dan ekspor pada tingkat sektoral.

Berdasarkan perubahan impor Indonesia dari China akibat diberlakukannya nol tarif pada tahun 2009 dan 2010, dapat terlihat bahwa pada tahun 2009, peningkatan impor Indonesia dari China sebesar US\$1,24 Milyar, sedangkan peningkatan impor Indonesia dari China pada tahun 2010 turun menjadi US $\$ 458,67$ Juta. Peningkatan produk impor Indonesia terbesar pada tahun 2009 adalah produk machinery and transport equipment sebesar US\$473,98 Juta, diikuti produk manufactured goods classified chiefly by materials sebesar US\$380,71 Juta dan produk miscellaneous manufactured articles sebesar US\$337,68 Juta. Ketiga jenis produk tersebut mendominasi 95,9 persen dari total perubahan impor Indonesia. Sedangkan pada tahun 2010, peningkatan produk impor Indonesia terbesar adalah produk machinery and transport equipment sebesar US\$180,64 Juta, diikuti produk miscellaneous manufactured articles sebesar US\$131,51 Juta dan produk manufactured goods classified chiefly by materials sebesar US\$109,93 Juta. 
Tabel 6

Dampak Liberalisasi Perdagangan RI-China Tahun 2009

(Perubahan Impor RI dari China)

\begin{tabular}{lcc}
\hline \multicolumn{1}{c}{ Product Description } & $\begin{array}{c}\text { SITC Division } \\
\text { Code }\end{array}$ & $\begin{array}{c}\text { Change in Import } \\
\text { (Million) }\end{array}$ \\
\hline Food and Live Animals Chiefly for Food & $(00-09)$ & 6,98 \\
Beverages and Tobacco & $(11-12)$ & 15,68 \\
Crude Materials, Inedible, Except Fuels & $(21-29)$ & 0,15 \\
Mineral Fuels, Lubricants and Related Materials & $(32-35)$ & 0,73 \\
Animal and Vegetable Oils, Fats and Waxes & $(41-43)$ & 0,07 \\
Chemicals and Related Products, n.e.s. & $(51-59)$ & 26,99 \\
Manufactured Goods Classified Chiefly by Materials & $(61-69)$ & 380,71 \\
Machinery and Transport Equipment & $(71-79)$ & 473,98 \\
Miscellaneous Manufactured Articles & $(81-89)$ & 337,68 \\
Commodities and Transactions not Classified Elsewhere & & 0,008 \\
in the SITC & &
\end{tabular}

Tabel 7

Dampak Liberalisasi Perdagangan RI-China Tahun 2010

(Perubahan Impor RI dari China)

\begin{tabular}{lcc}
\hline \multicolumn{1}{c}{ Product Description } & SITC Division Code & $\begin{array}{c}\text { Change in } \\
\text { Import (Million) }\end{array}$ \\
\hline Food and Live Animals Chiefly for Food & $(00-09)$ & 3,84 \\
Beverages and Tobacco & $(11-12)$ & 14,17 \\
Crude Materials, Inedible, Except Fuels & $(21-29)$ & 0,27 \\
Mineral Fuels, Lubricants and Related Materials & $(32-35)$ & 0,58 \\
Animal and Vegetable Oils, Fats and Waxes & $(41-43)$ & 0,43 \\
Chemicals and Related Products, n.e.s. & $(51-59)$ & 17,3 \\
Manufactured Goods Classified Chiefly by Materials & $(61-69)$ & 109,93 \\
Machinery and Transport Equipment & $(71-79)$ & 180,64 \\
Miscellaneous Manufactured Articles & $(81-89)$ & 131,51 \\
Commodities and Transactions not Classified Elsewhere in & & 0 \\
the SITC & &
\end{tabular}

Berdasarkan perubahan ekspor Indonesia ke China akibat diberlakukannya nol tarif pada tahun 2009 dan 2010, maka dapat terlihat bahwa pada tahun 2009, peningkatan ekspor Indonesia ke China sebesar US\$533,18 Juta dan pada tahun 2010 peningkatan ekspor lebih pesat lagi sebesar US\$714,63 Juta. Peningkatan ekspor RI ke China terbesar pada tahun 2009 adalah produk chemicals and related products sebesar US\$207,13 Juta diikuti produk mineral fuels, lubricants and related materials sebesar US\$159 Juta dan produk animal and vegetable oils, fats and waxes sebesar US\$114,22 Juta. Sedangkan pada tahun 2010, peningkatan ekspor RI ke 
China terbesar adalah produk crude materials, inedible, except fuels sebesar US\$313,89 Juta, diikuti oleh produk mineral fuels, lubricants and related materials sebesar US\$239,95 Juta dan produk animal and vegetable oils, fats and waxes sebesar US\$128,87 Juta. Maka berdasarkan netto perdagangan bilateral RI-China akibat diberlakukannya nol tarif pada tahun 2009 dan 2010, pada tahun 2009 net perdagangan RI diprediksi defisit sebesar US\$709,8 Juta, sedangkan pada tahun 2010 justru sebaliknya dimana net perdagangan RI surplus sebesar US\$255,96 Juta.

\section{Tabel 8}

Dampak Liberalisasi Perdagangan RI-China Tahun 2009

(Perubahan Ekspor RI ke China)

\begin{tabular}{lcc}
\hline \multicolumn{1}{c}{ Product Description } & $\begin{array}{c}\text { SITC Division } \\
\text { Code }\end{array}$ & $\begin{array}{c}\text { Change in Export } \\
\text { (Million) }\end{array}$ \\
\hline Food and Live Animals Chiefly for Food & $(00-09)$ & 3,19 \\
Beverages and Tobacco & $(11-12)$ & 0,48 \\
Crude Materials, Inedible, Except Fuels & $(21-29)$ & 4,94 \\
Mineral Fuels, Lubricants and Related Materials & $(32-35)$ & 159,01 \\
Animal and Vegetable Oils, Fats and Waxes & $(41-43)$ & 114,22 \\
Chemicals and Related Products, n.e.s. & $(51-59)$ & 207,13 \\
Manufactured Goods Classified Chiefly by Materials & $(61-69)$ & 17,53 \\
Machinery and Transport Equipment & $(71-79)$ & 12,06 \\
Miscellaneous Manufactured Articles & $(81-89)$ & 14,62 \\
Commodities and Transactions not Classified Elsewhere & & 0 \\
in the SITC & & \\
\hline Sumber: WITS 2012 & & \\
\hline
\end{tabular}

Sumber: WITS 2012

Tabel 9

Dampak Liberalisasi Perdagangan RI-China Tahun 2010

(Perubahan Ekspor RI ke China)

\begin{tabular}{lcc}
\hline \multicolumn{1}{c}{ Product Description } & $\begin{array}{c}\text { SITC Division } \\
\text { Code }\end{array}$ & $\begin{array}{c}\text { Change in Export } \\
\text { (Million) }\end{array}$ \\
\hline Food and Live Animals Chiefly for Food & $(00-09)$ & 3,89 \\
Beverages and Tobacco & $(11-12)$ & 0,59 \\
Crude Materials, Inedible, Except Fuels & $(21-29)$ & 313,89 \\
Mineral Fuels, Lubricants and Related Materials & $(32-35)$ & 239,95 \\
Animal and Vegetable Oils, Fats and Waxes & $(41-43)$ & 128,87 \\
Chemicals and Related Products, n.e.s. & $(51-59)$ & 8,1 \\
Manufactured Goods Classified Chiefly by Materials & $(61-69)$ & 14,03 \\
Machinery and Transport Equipment & $(71-79)$ & 5,07 \\
Miscellaneous Manufactured Articles & $(81-89)$ & 0,24 \\
Commodities and Transactions not Classified & & 0 \\
Elsewhere in the SITC & & \\
\hline Sumber: WITS 2012 & &
\end{tabular}

Sumber: WITS 2012 


\section{Dampak Liberalisasi Perdagangan RI-China terhadap Kesejahteraan Masyarakat di Indonesia (Penerapan SMART Model ke dalam SNSE 2008)}

Berdasarkan hasil olahan SMART diatas, maka kini penelitian ini memanfaatkan variabel perubahan impor dan ekspor untuk dimasukkan ke dalam model SNSE 2008, guna pada akhirnya melihat dampak trade shocks terhadap perubahan pendapatan rumah tangga dari masing-masing sektor. Tabel 10 memperlihatkan besaran nilai ekspor dan impor hasil perdagangan bilateral Indonesia-China pada tahun 2009 (setahun sebelum pemberlakuan kesepakatan nol tarif dalam kerangka ACFTA) dan tahun 2010 (dimana kesepakatan nol tarif ACFTA mulai berlaku).

Secara umum tarif yang berlaku pada tahun 2010 mengalami penurunan dibandingkan dengan tahun 2009, meski pada beberapa komoditi tertentu masih terdapat sedikit kenaikan tarif. Kenaikan tarif tersebut tampaknya merepresentasikan negosiasi kedua negara terhadap komoditi yang highly sensitif sehingga penurunannya mengalami penundaan sesuai kesepakatan bersama. Penurunan tarif impor yang diberlakukan China terhadap komoditi Indonesia tampaknya tidak begitu signifikan (perhatikan Tabel 10), sebaliknya penurunan tarif impor yang diberlakukan Indonesia terhadap komoditi China tampak sangat signifikan (perhatikan Tabel 10).

Tabel 10

Nilai Ekspor dan Impor Indonesia dari Perdagangan Bilateral RI-China 2009-2010

a) Nilai Ekspor Komoditi Indonesia ke China dan Rata-rata Tarif yang Berlaku

\begin{tabular}{|c|c|c|c|c|}
\hline \multirow{2}{*}{ Kelompok Komoditi } & \multicolumn{2}{|c|}{$\begin{array}{l}\text { Nilai Ekspor* } \\
\text { (Juta USD) }\end{array}$} & \multicolumn{2}{|c|}{$\begin{array}{c}\text { Rata-rata Tarif } \\
(\%)^{*}\end{array}$} \\
\hline & 2009 & 2010 & 2009 & 2010 \\
\hline 01 Pertanian Tanaman Pangan & 279,85 & 364,21 & 11,82 & 12,38 \\
\hline 02 Pertanian Tanaman Lainnya & 11,18 & 22,67 & 7,56 & 7,24 \\
\hline 03 Peternakan dan Hasil-hasilnya & 23,55 & 33,44 & 11,66 & 11,87 \\
\hline 04 Kehutanan dan Perburuan & 14,49 & 21,37 & 1,95 & 1,88 \\
\hline 05 Perikanan & 5,83 & 10,43 & 6,73 & 6,98 \\
\hline $\begin{array}{l}06 \text { Pertambangan Batubara, Biji Logam dan Minyak } \\
\text { Bumi }\end{array}$ & 2135,86 & 3311,29 & 0,39 & 0,30 \\
\hline 07 Pertambangan dan Penggalian Lainnya & 31,65 & 51,98 & 2,36 & 2,38 \\
\hline 08 Industri Makanan, Minuman dan Tembakau & 251,12 & 330,60 & 14,75 & 14,18 \\
\hline 09 Industri Pemintalan, Tekstil, Pakaian dan Kulit & 301,11 & 377,26 & 10,74 & 10,47 \\
\hline 10 Industri Kayu \& Barang dari Kayu & 81,68 & 126,27 & 1,85 & 1,86 \\
\hline $\begin{array}{l}11 \text { Industri Kertas, Percetakan, Alat Angkutan dan } \\
\text { Barang dari Logam dan Industri }\end{array}$ & $5.296,17$ & $7.002,19$ & 9,97 & 9,99 \\
\hline $\begin{array}{l}12 \text { Industri Kimia, Pupuk, Hasil dari Tanah Liat, } \\
\text { Semen }\end{array}$ & $1.915,32$ & $2.657,42$ & 7,60 & 7,55 \\
\hline Jumlah & 10347,81 & 14309,13 & $\mathbf{9 , 5 1}$ & 9,44 \\
\hline
\end{tabular}

Keterangan:

*) Nilai ekspor dan tarifnya diperoleh dari laporan impor barang masuk ke China yang berasal dari Indonesia 
b) Nilai Impor Komoditi China yang Masuk ke Indonesia dan Rata-Rata Tarif yang Berlaku

\begin{tabular}{|c|c|c|c|c|}
\hline \multirow[t]{2}{*}{ Kelompok Komoditi } & \multicolumn{2}{|c|}{$\begin{array}{l}\text { Nilai Impor* } \\
\text { (Juta USD) }\end{array}$} & \multicolumn{2}{|c|}{$\begin{array}{c}\text { Rata-rata Tarif } \\
(\%)^{*}\end{array}$} \\
\hline & 2009 & 2010 & 2009 & 2010 \\
\hline 01 Pertanian Tanaman Pangan & 359,80 & 606,38 & 2,41 & 2,46 \\
\hline 02 Pertanian Tanaman Lainnya & 130,91 & 198,69 & 3,82 & 3,07 \\
\hline 03 Peternakan dan Hasil-hasilnya & 67,59 & 119,77 & 2,59 & 2,82 \\
\hline 04 Kehutanan dan Perburuan & 0,65 & 1,31 & 0,35 & 0,71 \\
\hline 05 Perikanan & 0,25 & 7,53 & 3,33 & 2,61 \\
\hline $\begin{array}{l}06 \text { Pertambangan Batubara, Biji Logam dan Minyak } \\
\text { Bumi }\end{array}$ & 318,95 & 779,48 & 2,04 & 2,49 \\
\hline 07 Pertambangan dan Penggalian Lainnya & 71,55 & 77,63 & 1,49 & 1,86 \\
\hline 08 Industri Makanan, Minuman dan Tembakau & 600,43 & $1.118,46$ & 11,82 & 3,58 \\
\hline 09 Industri Pemintalan, Tekstil, Pakaian dan Kulit & 770,08 & $1.232,71$ & 4,23 & 3,56 \\
\hline 10 Industri Kayu \& Barang Dari Kayu & 44,98 & 75,12 & 1,91 & 0,80 \\
\hline $\begin{array}{l}11 \text { Industri Kertas, Percetakan, Alat Angkutan dan } \\
\text { Barang dari Logam dan Industri }\end{array}$ & $8.018,14$ & $\begin{array}{r}10.808,0 \\
5\end{array}$ & 5,15 & 3,92 \\
\hline 12 Industri Kimia, Pupuk, Hasil Dari Tanah Liat, Semen & $4.385,09$ & $6.437,79$ & 3,83 & 3,10 \\
\hline Jumlah & $\begin{array}{r}14.771,4 \\
2\end{array}$ & $\begin{array}{r}21.463,0 \\
5\end{array}$ & 5,01 & 3,50 \\
\hline
\end{tabular}

\section{Keterangan:}

*) Nilai impor dan tarifnya diperoleh dari laporan impor barang masuk ke Indonesia yang berasal dari China.

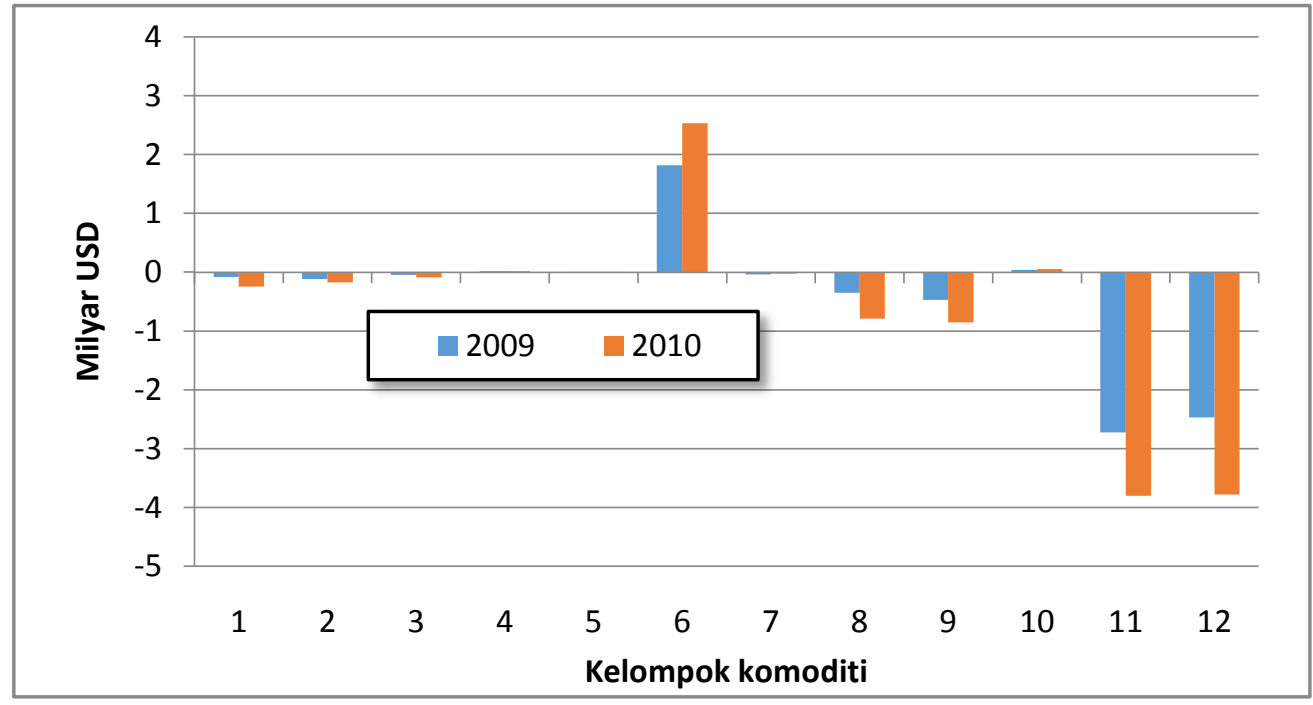

Gambar 3

Neraca Perdagangan (Net Export) Perdagangan Bilateral RI-China 2009-2010

Kode Kelompok Komoditi: (1) Pertanian Tanaman Pangan; (2) Pertanian Tanaman Lainnya; (3) Peternakan dan Hasil-hasilnya; (4) Kehutanan dan Perburuan; (5) Perikanan; (6) Pertambangan Batubara, Biji Logam dan Minyak Bumi; (7) Pertambangan dan Penggalian Lainnya; (8) Industri Makanan, Minuman dan Tembakau; (9) Industri Pemintalan, Tekstil, Pakaian dan Kulit; (10) Industri Kayu \& Barang Dari Kayu; (11) Industri Kertas, Percetakan, Alat Angkutan dan Barang Dari Logam dan Industri; (12) Industri Kimia, Pupuk, Hasil Dari Tanah Liat, Semen; 
Tabel 11

Perubahan Nilai Ekspor dan Impor Berdasarkan Hasil Simulasi SMART Model (Juta USD)

\begin{tabular}{lrrrr}
\hline \multicolumn{1}{c}{ Kelompok Komoditi } & Perubahan Ekspor & \multicolumn{2}{c}{ Perubahan Impor } \\
& $\mathbf{2 0 0 9}$ & $\mathbf{2 0 1 0}$ & $\mathbf{2 0 0 9}$ & $\mathbf{2 0 1 0}$ \\
\hline 01 Pertanian Tanaman Pangan & 0,00 & 0,00 & 0,00 & 0,00 \\
02 Pertanian Tanaman Lainnya & 1,57 & 2,59 & 0,00 & 0,00 \\
03 Peternakan dan Hasil-hasilnya & 0,00 & 0,00 & 0,00 & 0,00 \\
04 Kehutanan dan Perburuan & 0,08 & 0,00 & 0,00 & 0,00 \\
05 Perikanan & 1,24 & 0,00 & 0,00 & 0,00 \\
06 Pertambangan Batubara, Biji Logam dan & 0,00 & 0,00 & 0,00 & 0,00 \\
$\quad$ Minyak Bumi & & & & \\
07 Pertambangan dan Penggalian Lainnya & 0,00 & 0,00 & 0,00 & 0,00 \\
08 Industri Makanan, Minuman dan Tembakau & 110,95 & 131,30 & 22,67 & 18,09 \\
09 Industri Pemintalan, Tekstil, Pakaian dan Kulit & 15,97 & 0,53 & 414,19 & 108,32 \\
10 Industri Kayu \& Barang Dari Kayu & 1,10 & 0,37 & 8,70 & 0,00 \\
11 Industri Kertas, Percetakan, Alat Angkutan dan & 26,67 & 18,52 & 645,01 & 218,08 \\
$\quad$ Barang dari Logam dan Industri & & & & \\
12 Industri Kimia, Pupuk, Hasil dari Tanah Liat, & 189,21 & 561,32 & 152,43 & 114,19 \\
$\quad$ Semen & & & & \\
Jumlah & $\mathbf{3 4 6 , 7 8}$ & $\mathbf{7 1 4 , 6 3}$ & $\mathbf{1 2 4 2 , 9 9}$ & $\mathbf{4 5 8 , 6 8}$ \\
\hline
\end{tabular}

Tabel 11 memperlihatkan perubahan nilai ekspor dan impor yang terjadi bilamana nol tarif diberlakukan secara penuh pada tahun 2009 dan 2010. Pada kelompok komoditi pertanian, tampak masih terdapat perubahan ekspor sebaliknya impor produk pertanian sudah tidak terjadi lagi. Hal ini menunjukkan bahwa pemberlakuan nol tarif secara penuh di tahun 2009 berdampak positif terhadap ekspor komoditi Indonesia dan secara implisit menunjukkan bahwa tarif yang diberlakukan China terhadap komoditi Indonesia merupakan hambatan yang cukup berarti bagi komoditi pertanian Indonesia. Dengan diberlakukannya nol tarif pada tahun 2010, tampak bahwa China tidak dapat lagi menghambat pemasukan komoditi Indonesia dengan tarif yang lebih tinggi karena kesepakatan nol tarif ACFTA telah diberlakukan. Pada tabel ini juga memperlihatkan sisi positif dari diberlakukannya nol tarif pada komoditi petanian non tanaman pangan yang menunjukkan perubahan yang positif di tahun 2010. Secara umum tidak terdapatnya perubahan impor pada komoditi pertanian setidaknya menunjukkan bahwa pemberlakuan nol tarif sudah mulai berlaku sejak awal disepakatinya ACFTA (Early Harvest Period) sehingga pada simulasi yang dihasilkan tidak terdapat perbedaan tarif yang terjadi di tahun 2010 .

Di lain pihak, kelompok komoditi industri menunjukkan perubahan ekspor maupun impor yang cukup signifikan. Meski pada beberapa komoditi perubahan tersebut semakin berkurang (dalam arti pertambahan nilai yang diperoleh semakin berkurang), akan tetapi perubahan pada beberapa komoditi industri lainnya telah 
berhasil mengangkat perubahan nilai ekspor yang lebih tinggi (pada tahun 2009 total perubahan ekspor sebesar US\$345 Juta, sedangkan pada tahun 2010 perubahan yang terjadi sebesar US\$715 Juta). Penurunan perubahan nilai impor juga menunjukkan sisi positif dari pemberlakuan nol tarif secara penuh. Secara total peningkatan nilai impor yang pada tahun 2009 sebesar US\$1,25 Milyar, di tahun 2010 peningkatan nilai impor berkurang hampir mencapai 75 persen menjadi sebesar US $\$ 0,5$ Milyar. Terlihat dalam tabel tersebut perubahan yang cukup signifikan terjadi pada komoditi (8) industri makanan, minuman dan tembakau; (9) industri pemintalan, tekstil, pakaian dan kulit dan (12) industri kimia, pupuk, hasil dari tanah liat, semen.

Tabel 12

Neraca Perdagangan (Net Export) Perdagangan Bilateral RI-China

Hasil Simulasi Nol Tarif menggunakan SMART Model

\begin{tabular}{lrr}
\hline \multicolumn{1}{c}{ Sub Sektor } & \multicolumn{2}{c}{ Net Export (Juta USD) } \\
& $\mathbf{2 0 0 9}$ & \multicolumn{1}{c}{$\mathbf{2 0 1 0}$} \\
\hline 01 Pertanian Tanaman Pangan & $-79,95$ & $-242,17$ \\
02 Pertanian Tanaman Lainnya & $-118,16$ & $-173,44$ \\
03 Peternakan dan Hasil-hasilnya & $-44,04$ & $-86,32$ \\
04 Kehutanan dan Perburuan & 13,92 & 20,06 \\
05 Perikanan & 3,82 & 2,90 \\
06 Pertambangan Batubara, Biji Logam dan Minyak & $1.816,91$ & $2.531,81$ \\
$\quad$ Bumi & & \\
07 Pertambangan dan Penggalian Lainnya & $-39,90$ & $-25,64$ \\
08 Industri Makanan, Minuman dan Tembakau & $-261,04$ & $-674,65$ \\
09 Industri Pemintalan, Tekstil, Pakaian dan Kulit & $-867,20$ & $-963,24$ \\
10 Industri Kayu \& Barang Dari Kayu & 29,11 & 51,52 \\
11 Industri Kertas, Percetakan, Alat Angkutan dan & $-3.340,30$ & $-4.005,42$ \\
$\quad$ Barang Dari Logam dan Industri & & \\
12 Industri Kimia, Pupuk, Hasil Dari Tanah Liat, & $-2.432,98$ & $-3.333,24$ \\
$\quad$ Semen & & \\
$\quad$ Total & $\mathbf{- 5 . 3 1 9 , 8 2}$ & $\mathbf{- 6 . 8 9 7 , 9 7}$ \\
\hline
\end{tabular}

Perubahan yang positif dari nilai ekspor dan impor juga membawa dampak yang positif berupa peningkatan surplus neraca perdagangan dari komoditi yang mengalami surplus. Sebaliknya pada komoditi yang mengalami defisit neraca perdagangan, pertambahan nilai ekspor dan impor justru mengakibatkan semakin besarnya defisit yang terjadi. Seperti terlihat dalam Tabel 12 peningkatan defisit neraca perdagangan dialami oleh komoditi pertanian, peternakan dan industri, sedangkan peningkatan surplus neraca perdagangan dialami oleh kelompok komoditi kehutanan \& perburuan, perikanan, pertambangan migas, serta industri kayu.

Secara umum meski pemberlakuan nol tarif membawa dampak positif pada pertambahan nilai ekspor maupun impor, akan tetapi nilai impor yang jauh lebih tinggi dari nilai ekspor telah mengakibatkan neraca perdagangan Indonesia menjadi 
defisit. Oleh karena itu, semestinya pemerintah harus lebih kuat lagi memotivasi pengusaha untuk meningkatkan ekspor dan menyadarkan masyarakat agar lebih mencintai produk dalam negeri untuk mengurangi pertambahan nilai ekspor yang sudah jauh melebihi nilai ekspor.

Selanjutnya penghitungan dampak yang diakibatkan oleh adanya pemberlakuan nol tarif terhadap pendapatan rumah tangga dilakukan dengan prosedur/langkah kedua seperti yang telah dijelaskan dalam paragraf sebelumnya. Hasil penghitungan diperlihatkan dalam Tabel 13. Sebagaimana halnya dengan nilai ekspor dan impor yang mengalami peningkatan, pemberlakuan nol tarif juga berdampak pada meningkatnya pendapatan (sebagai akibat dari ekspor komoditi Indonesia ke China) dan pengeluaran rumah tangga (sebagai akibat dari impor komoditi China yang masuk ke Indonesia). Hasil simulasi pemberlakuan nol tarif menunjukkan bahwa pengeluaran rumah tangga akibat impor lebih tinggi dibandingkan dengan peningkatan pendapatan rumah tangga akibat ekspor. Meski demikian, perubahan yang terjadi akibat pemberlakuan nol tarif jika dibandingkan dengan perdagangan yang dikenakan tarif menunjukkan dampak yang positif. Hal ini terlihat dari meningkatnya pertambahan pendapatan akibat ekspor dan menurunnya pertambahan pengeluaran akibat impor (perhatikan Tabel 13 pada kolom $\Delta$ ).

Tabel 13

Dampak Pemberlakuan Nol Tarif pada Perdagangan Bilateral RI-China terhadap Kesejahteraan (Juta USD)

\begin{tabular}{lcccccccc}
\hline \multicolumn{1}{c}{$\begin{array}{c}\text { Rumah } \\
\text { Tangga }\end{array}$} & \multicolumn{4}{c}{ Pendapatan Rumah Tangga Akibat } & \multicolumn{4}{c}{ Pengeluaran Rumah Tangga } \\
& $\mathbf{2 0 0 9}$ & \multicolumn{1}{c}{$(\Delta)$} & $\mathbf{2 0 1 0}$ & $(\Delta)$ & $\mathbf{2 0 0 9}$ & \multicolumn{1}{c}{$(\Delta)$} & $\mathbf{2 0 1 0}$ & $(\Delta)$ \\
\hline 01 Buruh Tani & 1,10 & 0,04 & 1,54 & 0,08 & 1,83 & 0,14 & 2,51 & 0,05 \\
02 Petani & 4,54 & 0,16 & 6,38 & 0,32 & 7,59 & 0,60 & 10,40 & 0,22 \\
03 RTR Desa & 3,10 & 0,11 & 4,36 & 0,21 & 5,05 & 0,40 & 6,93 & 0,15 \\
04 RTM Desa & 1,07 & 0,04 & 1,51 & 0,07 & 1,77 & 0,14 & 2,43 & 0,05 \\
05 RTA Desa & 2,98 & 0,10 & 4,20 & 0,21 & 4,82 & 0,38 & 6,60 & 0,14 \\
06 RTR Kota & 4,57 & 0,15 & 6,42 & 0,30 & 7,25 & 0,57 & 9,93 & 0,21 \\
07 RTM Kota & 1,58 & 0,05 & 2,22 & 0,11 & 2,49 & 0,20 & 3,43 & 0,07 \\
08 RTA Kota & 5,34 & 0,18 & 7,52 & 0,36 & 8,52 & 0,68 & 11,66 & 0,25 \\
Total & $\mathbf{2 4 , 2 7}$ & $\mathbf{0 , 8 3}$ & $\mathbf{3 4 , 1 6}$ & $\mathbf{1 , 6 5}$ & $\mathbf{3 9 , 3 2}$ & $\mathbf{3 , 1 2}$ & $\mathbf{5 3 , 8 9}$ & $\mathbf{1 , 1 5}$ \\
\hline
\end{tabular}

Keterangan: $(\Delta)$ menunjukkan besarnya perubahan (pendapatan/pengeluaran rumah tangga) yang terjadi akibat pemberlakuan nol tarif terhadap perdagangan dengan tarif.

Dampak positif juga diperlihatkan dari besarnya perubahan pada dampak netto (pendapatan rumah tangga akibat ekspor minus pendapatan rumah tangga akibat impor). Pendapatan netto yang diterima rumah tangga akibat perdagangan luar negeri dengan China masih negatif, dalam arti besarnya pengeluaran rumah tangga akibat membanjirnya komoditi China ke Indonesia masih jauh lebih besar dibandingkan dengan pendapatan yang diterima rumah tangga sebagai dampak dari 
ekspor komoditi Indonesia ke China (perhatikan Tabel 14). Sisi positif dari pemberlakuan nol tarif dalam perdagangan bilateral Indonesia-China adalah semakin bertambahnya pendapatan netto. Jika pada tahun 2009 perubahan dampak netto masih menunjukkan nilai yang negatif, maka di tahun 2010 perubahan dampak netto telah menunjukkan angka yang positif (lihat Tabel 14 pada kolom $\Delta$ ). Pendapatan netto yang negatif terjadi karena nilai impor yang lebih besar daripada nilai ekspor. Oleh karena itu bertambahnya pendapatan netto yang diterima rumah tangga akan sangat dirasakan apabila pemerintah (dan juga pelaku usaha) dapat mengupayakan peningkatan nilai ekspor hingga bisa melebihi nilai impor.

Peningkatan pendapatan netto dirasakan di semua jenis rumah tangga. Peningkatan pendapatan terbesar pada rumah tangga non pertanian dirasakan oleh rumah tangga di daerah perkotaan. Peningkatan yang terjadi antara rumah tangga berpenghasilan rendah (RTR) maupun menengah ke atas (RTA) hampir berimbang, sementara rumah tangga berpenghasilan minim (RTM) hanya merasakan peningkatan yang paling rendah. Untuk rumah tangga pertanian, rumah tangga buruh tani juga mengalami peningkatan, hanya saja tidak sebesar yang dirasakan oleh rumah tangga petani. Jika dibandingkan dengan rumah tangga non pertanian di pedesaan, maka peningkatan pendapatan yang diperoleh petani sedikit lebih kecil dibandingkan dengan rumah tangga berpenghasilan rendah.

Tabel 14

Pendapatan Netto Akibat Perdagangan Luar Negeri RI-China (Juta USD)

\begin{tabular}{|c|c|c|c|c|}
\hline \multirow{2}{*}{$\begin{array}{l}\text { Rumah } \\
\text { Tangga }\end{array}$} & \multicolumn{4}{|c|}{ Dampak Netto Pendapatan Rumah Tangga } \\
\hline & 2009 & $(\Delta)$ & 2010 & $(\Delta)$ \\
\hline 01 Buruh Tani & $-0,73$ & $-0,11$ & $-0,97$ & 0,02 \\
\hline 02 Petani & $-3,05$ & $-0,44$ & $-4,02$ & 0,09 \\
\hline 03 RTR Desa & $-1,95$ & $-0,29$ & $-2,57$ & 0,07 \\
\hline 04 RTM Desa & $-0,69$ & $-0,10$ & $-0,92$ & 0,02 \\
\hline 05 RTA Desa & $-1,83$ & $-0,28$ & $-2,40$ & 0,06 \\
\hline 06 RTR Kota & $-2,69$ & $-0,42$ & $-3,51$ & 0,09 \\
\hline 07 RTM Kota & $-0,91$ & $-0,15$ & $-1,20$ & 0,03 \\
\hline 08 RTA Kota & $-3,18$ & $-0,50$ & $-4,14$ & 0,11 \\
\hline Total & $-15,05$ & $-2,30$ & $-19,73$ & $\mathbf{0 , 5 0}$ \\
\hline
\end{tabular}

\section{SIMPULAN DAN REKOMENDASI KEBIJAKAN}

Dampakliberalisasi perdagangan RI-China (2009 dan 2010) terhadap kesejahteraan masyarakat diukur berdasarkan besarnya perubahan pada dampak netto (pendapatan rumah tangga akibat ekspor minus pendapatan rumah tangga akibat impor). Pendapatan netto yang diterima rumah tangga akibat perdagangan luar negeri dengan China masih negatif, dalam arti besarnya pengeluaran rumah tangga akibat besarnya komoditi China ke Indonesia masih jauh lebih besar dibandingkan dengan 
pendapatan yang diterima rumah tangga sebagai dampak dari ekspor komoditi Indonesia ke China. Sisi positif dari pemberlakuan nol tarif dalam perdagangan bilateral Indonesia-China adalah semakin bertambahnya pendapatan netto. Jika pada tahun 2009 perubahan dampak netto masih menunjukkan nilai yang negatif, maka di tahun 2010 perubahan dampak netto telah menunjukkan angka yang positif. Pendapatan netto yang negatif terjadi karena nilai impor yang lebih besar daripada nilai ekspor. Oleh karena itu bertambahnya pendapatan netto yang diterima rumah tangga akan sangat dirasakan apabila pemerintah (dan juga pelaku usaha) dapat mengupayakan peningkatan nilai ekspor hingga bisa melebihi nilai impor.

Peningkatan pendapatan netto dirasakan di semua jenis rumah tangga. Peningkatan pendapatan terbesar pada rumah tangga non pertanian dirasakan oleh rumah tangga di daerah perkotaan. Peningkatan yang terjadi antara rumah tangga berpenghasilan rendah (RTR) maupun menengah ke atas (RTA) hampir berimbang, sementara rumah tangga berpenghasilan minim (RTM) hanya merasakan peningkatan yang paling rendah. Untuk rumah tangga pertanian, rumah tangga buruh tani juga mengalami peningkatan, hanya saja tidak sebesar yang dirasakan oleh rumah tangga petani. Jika dibandingkan dengan rumah tangga non pertanian di pedesaan, maka peningkatan pendapatan yang diperoleh petani sedikit lebih kecil dibandingkan dengan rumah tangga berpenghasilan rendah.

Berdasarkan analisa diatas, maka beberapa saran yang dapat dilakukan oleh para pengambil kebijakan adalah: (1) pemerintah kiranya dapat memberikan bantuan dalam rangka memperkuat daya saing kepada rumah tangga non-pertanian yang berpenghasilan minim (RTM) baik di desa maupun kota serta rumah tangga buruh tani sehingga ke depannya pemerataan kesejahteraan masyarakat atau pendapatan di seluruh jenis rumah tangga dapat tercapai; (2) liberalisasi perdagangan RI-China ternyata hanya berdampak terhadap sektor manufaktur dan secara keseluruhan ekspor RI ke China lebih besar daripada impor RI dari China, sehingga pada akhirnya berdampak terhadap pendapatan rumah tangga yang lebih besar daripada pengeluaran rumah tangga.

Berdasarkan besarnya kontribusi subsektor manufaktur terhadap peningkatan pendapatan masyarakat, maka pemerintah dalam hal ini, arah dan strategi kebijakan dalam pembangunan sektor produksi adalah melalui bantuan (misalnya melalui penguatan alokasi pendanaan dan dukungan lainnya) pada sektor manufaktur (berdasarkan prioritas/ranking) yaitu: 1) industri kimia, pupuk, hasil dari tanah liat, semen (subsektor 12); 2) industri permintalan, tekstil, pakaian dan kulit (subsektor 09); 3) industri makanan, minuman dan tembakau (subsektor 08); dan 4) industri kertas, percetakan, alat angkutan dan barang dari logam dan industri (subsektor 11) guna terus memperkuat daya saing produk manufaktur Indonesia dan pada akhirnya memberikan sumbangsih yang besar terhadap pendapatan masyarakat Indonesia. 


\section{DAFTAR PUSTAKA}

Badan Pusat Statistik. 2010.Sistem Neraca Sosial Ekonomi Indonesia. Jakarta.

Chandra, A. C., dan L. A. Lontoh. 2011. Indonesia-china trade relations: The deepening of economic integration amid uncertainty? Trade Knowledge Network. Available athttp://www.iisd.org.

Krugman, P. R., dan M. Obstfeld. 2005. International Economics: Theory and Policy, Edisi ke-7. Boston: Addison-Wesley.

Nopirin. 1995. Ekonomi Internasional. Yogyakarta: Badan Penerbit Fakultas Ekonomi Universitas Gadjah Mada.

Plummer, M. G., D. Cheong, dan S. Hamanaka. 2010. Methodology for impact assessment of free trade agreements. Mandaluyong City. Asian Development Bank.Available at http://aric.adb.org.

Widjaja, A. 2000. Dampak liberalisasi perdagangan terhadap kinerja ekonomi Indonesia: Suatu pendekatan makroekonometrika. Disertasi. Institut Pertanian Bogor. Available at http://repository.ipb.ac.id.

World Integrated Trade Solutions/TRAINS. 2003. Database on International Trade and Tariffs, UNCTAD-World Bank Jenewa dan Washington. 